\title{
Portrayal of Women in the Short Stories of Khushwant Singh
}

\author{
V. G. Sadh \\ IPS Academy, Institute of Engineering and Science, Indore, India
}

\begin{abstract}
As one takes up Khushwant Singh's collection of short stories, the first thing that strikes the eye is the immense variety, his stories depict. He has written on every plausible topic between heaven and earth. Stories are dealing with the supernatural with suspense, with children, with animals, with the human relationship of all shades and kinds, with the different professions, trades, vocations, etc. With various social evils, customs, traditions, superstition, etc. sometimes in a hilarious, sometimes in an ironic vein. There are stories of retribution and revenge of love and sex of ironic contrast and situations and pure humor or comedy or those in which humor mingles with pathos. There are stories of character which bring out Khushwant Singh's deep insight into human psychology especially women's psychology. Some stories arouse our pity and curiosity for the downs and outs of a society-a beggar, a woman of loose character, and other socially rejected and discarded types. Although the period was not permitting a woman to do what she wishes still he portrays the empowerment of women in his stories. He intends to unleash the concealed power of women after all the complex situations. The present study is focused on the representation of women in the short stories with a feministic approach.
\end{abstract}

\section{KEY WORDS: SHORT STORIES, WOMEN, SUBLIME, DISCRIMINATION.}

\section{INTRODUCTION}

Every character mainly deals with men and women existing in culture and society. These characters possess a personality of their own and act in and out of society. Characterization thus becomes an essential part of the Short story, Fiction, or Novel. The excellence of the short story writer can well be discovered from the number of finished characters that he has created. A great short story writer must know how to weave characters in the web of life and yet return within their respective individual qualities and universal patterns. For "Characters that have a universal appeal are the life of a novel or short story".

Khushwant Singh has introduced his woman characters in their social context with a purpose. His woman characters are usually two-dimensional and firmly interlinked with

Biosc Biotech Res Comm P-ISSN: 0974-6455 E-ISSN: 2321-4007
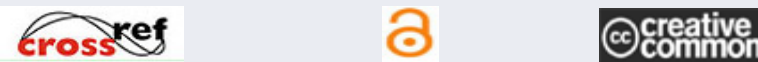

Identifiers and Pagination

Article Information

Year: 2021 Vol: 14 No (8) Special Issue

Received: $05^{\text {th }}$ June 2021

Pages: $143-145$ Accepted after revision: $24^{\text {th }}$ July 2021

This is an open access article under Creative

Commons License Attribn 4.0 Intl (CC-BY).

DOI: $h t t p: / / d x . d o i . o r g / 10.21786 / b b r c / 14.8 .32$ the situation and atmosphere. He uses the principle of the center which differentiates one character from one another. Mostly the characterization is done through direct comments made by a knowing narrator. The behavior of woman characters when placed in a critical situation and their different points of view also differentiate them. The devices such as parallelism and contrast and the use of nonverbal modes of communication such as parallelism and contrast such as gestures, manners, and typical dialogue also help the writer to present his character distinctly and establish them within a realistic sociocultural framework. Khushwant Singh's characterization can be studied such as love, sex, religion, superstition, death, and so on, which are of great social significance in the Indian context. There are several stories in which the sharply contrasted woman characters help to illumine the central idea. These characters can be analyzed based on their social, regional, cultural, and educational differences.

Nobility And Purity: 'The portrait of A Lady' is another example in which the central character is effectively individualized. This is the picture of the narrator's grandmother whose face was a crisscross of wrinkles running from everywhere to everywhere. "She was an 
extremely pious woman and spent a great deal of her time in a village temple. She believes purely in God, prayers and good deeds, kindness, love, and humanity. She says her prayers even while she works at her home while dressing her grandchild while going to the temple and every moment when she has nothing to speak in particular she counts the beads of her rosary. Her devotion was the only reflection of her faith in God. She does never speak about it to anyone and keeps performing her duties. When her grandson was with her she took every care of him and provided him with everything which he needed, even the love of his mother and affection of a father. Moreover, she was aware of the responsibility towards making her grandson, a cultured person.

This is why she used to sing the prayers in a "monotonous sing-song' manner. While both of them return home and when she came to the city she started to give crumbs of bread to the sparrows. She did whatever she wanted to and whatever she could without disturbing anyone." Her heart was full of love for everyone whether it is her grandson or the sparrows or the village dogs but the love she had in her heart was of a different type. She was a detached lover whose love for everybody was hidden deep in her heart but she did never weep for it. Her heart was not sad when she left the village and the temple and dogs didn't cry to get her back to place. She took to sparrows instead of dogs and was happy with them. She did not weep or show any sentiments even when her grandson went abroad and was not very happy when he came back after five years. The writer remarks,

"She still has no time for words and while she clasped me in her arms I could hear her reciting her prayers. Even on the first day of my arrival, her happiest moments were with her sparrows that she fed longer and with frivolous rebukes." She was like a saint who had no worldly desires and who did not want anything in return for whatever she did to others. And this love was the language even the birds could understand who did not eat single Crum spread by the writer's mother and "flew away quietly" as the people carried her corpse off. The character of the grandmother is the most sublime character, Khushwant Singh has ever produced. Perhaps that is the reason why the story is prescribed in the textbook of children. And this is the only story on which a book has been written by Darshan Singh Maini. 'The Portrait of A Lady - An Assessment' published in 1977.

Discriminations With The Women: The story Karma demonstrates Hindu religion means bad or good luck, considered as consequent from one's action. 'Karma' depicts the slavish psychology of the educated Indian in British India and is marked by irony and inversion. Sir Mohanlal is a study in alienation; he deliberately dissociated himself from his native soil and cultural roots. However, except in his dress, he is not English at all. His dislikes go to the extent that does not even talk to his wife who always takes care of him and for the relatives of the wife are illiterate and poor, he does not even allow them to enter his house. He only respects English people and hates even his wife who is a simple Indian illiterate lady, who has no manners for him. But a dignity, which is false and the pride for nothing don't remain for a long time in the life of a man. So Sir Mohanlal pays the price for this artificially contrived exclusiveness from his native setting and is being flung out of the railway's compartment by the British Soldiers.

In the story 'The Black Jasmine', Martha is a Negress, too much black but very attractive to look at, and very dominant. She can smartly tackle the boys who make passes at her but she was always full of desire too and could easily seduce the boys who just kept on seducing her. She makes friends with Indian-born Banerjee. She makes this timid boy full of passion for her beautiful figure. Banerjee becomes so bewitched by her and likes her so much that he cannot forget her even after thirty years, a father of two grown-up children; he still has a desire for her and so is with Martha.

Women Suffocation: 'Kusum' is a story of an introverted teenage girl who has become a captive of her psyche fences. She was short, fat, dark, and wore gold-rimmed glasses which made her look older than her age. She shunned sex and even the idea of the company of men frightened her. She looked like a virtuous 'auntie' and positively disliked the gift of lipstick by her friends on her nineteenth birthday. Kusum felt that with the conclusion of her degree examination a vacuum had descended on her. As she rode a bicycle, she encountered a poor hawker on the street. She lost her temper but the one-eyed hawker was so provoked that he manipulated a long, lecherous wink and the sound of a loud kiss. The street was deserted and he accosted her; this unexpected gesture created an intense sensation in Kusum's inner being.

It acted as a stimulus to her repressed self to break all barriers and she becomes a natural physically normal girl and asserts her inner appetite. That gesture was the mark of the psychic release which enabled her to begin realizing her true self. She loosened her hair, used lipstick, and stood before the mirror, admiring herself. Although Kusum has a thing structures the Freudian element is unmistakably operative in the mental process of the principal character. In the stories of Khushwant Singh when he talks of love sex, his women characters also get equal importance. He has deep insight and understanding of human psychology. Singh portrays the preponderantly physical reality of a woman's passion for man and man's irrepressible desire for a woman and creates an effect of surprise. Whether it is Bindo or Dalip Singh in 'The Rape' or Moola Singh's pretty daughter and Hansen in 'The Punjab Pastoral' or Martha the black negress and Banerjee in 'Black Jasmine' or Kusum in 'Kusum'

\section{CONCLUSION}

Khushwant Singh is a widely traveled man and insists that he has seen all that is worth seeing in this world. What makes Khushwant Singh's travelogues special is his total lack of inhibition. He tells it all as he saw it, missing out on nothing, whether it was a rebutted pass 
at a girl, a joke of his expense, or the fun and follies of the individual or the persons or a lecherous intention that came to nothing. He depicts characters and situations that are outside the limits of the rational and yet appear truer than real-life characters and commonly existing situations. His portrayal of a woman character in all the short stories has created an indelible impression in the mind of the readers. His characters possess the caliber to do beyond imagination but the domination and suppression conceal it. His stories portray the factual plight of the woman of that era. His stories talk about the follies and false manhood and on the other hand, he empowers her woman characters in his short stories.

\section{REFERENCES}

Acharjee, B. \&t Ramamoorthy, R. (2018). Frontiers of Communication: An Anthology of short stories and prose. Cambridge University Press India Pvt. Ltd., New Delhi

Hale, Nancy. (1963). The Realities of A Fiction London. Macmillan \&t Company

Iyernagar, K.R.S. (1985). Indian Writing in English. New Delhi: Sterling Publishers

Khan, M.Q. (1995). Changing Faces of Women in Indian writing in English. New Delhi: Creative Books.

Sailaja, P. (2000). English and Indian Short Story. New Delhi: Orient Longman Ltd. Print

Singh, Khushwant. (1989). The Collected short stories of Khushwant Singh. New Delhi: Ravidayal Publishers 